\title{
Identification of Factors that Impact on Syariah Bank Asset Growth in West Java Province
}

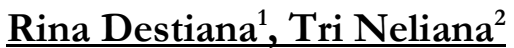 \\ 1,2Universitas Swadaya Gunung Jati, Indonesia \\ Email: destirin@gmail.com
}

\section{Abstract:}

The syariah banking industry in Indonesia is experiencing various growth in accordance with national economic growth. One indicator of the growth of syariah banks can be seen from the growth in assets. The phenomenon of decreasing asset growth that occurs in syariah banks encourages the need for further research. This study aims to determine and analyze the effect of the number of office networks, Non Performing Financing, Financing to Deposit Ratio, returns on third party funds and the BI rate on the growth of syariah bank assets in West Java Province. This study uses secondary data published by the Financial Services Authority and Bank Indonesia. The research period is January 2016 to December 2019. The data analysis method used in this study is multiple linear regression analysis, which previously tested the classical assumptions and then tested the hypothesis. The results showed that only the return on third party funds had an effect on asset growth, while the number of office networks, NonPerforming Financing, Financing to Deposit Ratio and BI rate had no effect on the growth of syariah bank assets in West Java Province.

Keywords:

office network; yield; NPF; FDR; BI rate; asset growth

\section{Introduction}

The strategic role of the Islamic banking industry in the people's economic development must be continuously improved by capturing the various opportunities that exist in the digital financial era marked by the use of technology in banking products. The Islamic banking industry in Indonesia is experiencing various growth in accordance with national economic growth (1).

The growth of Islamic banking tends to grow not as well as it should be, when viewed based on the existing potential. This can be seen from the condition of the people of Indonesia, which is the largest Muslim country in the world, but the development of Islamic banking in Indonesia tends to be very minimal when compared to other Muslim countries.

One indicator of the growth of Islamic banks can be seen from the growth in assets. Since the emergence of Islamic banks in society until now, the total assets of Islamic banks have increased from year to year. However, after a closer look, the data shows that from 2012 to 2015, and from 2017 to the end of 2019, the growth of Islamic bank assets actually decreased. The following is presented data on the growth of assets of BUS and UUS in Indonesia from 2010 to 2019: 


\section{Economit Journal: Scientific Journal of Accountancy, Management and Finance ISSN: 2775-5827 (Online), 2775-5819 (Print)}

Vol. 1, No. 1, February 2021, Page: 1-11

Email: economitjournal@gmail.com

Table 1. Growth of Islamic Bank Assets in Indonesia 2010-2019

\begin{tabular}{|c|c|c|}
\hline \multirow{2}{*}{ Year } & Asset & \multirow{2}{*}{ Asset Growth } \\
\cline { 2 - 2 } & (billion Rp) & \\
\hline Dec 2009 & 66.090 & \\
\hline Dec 2010 & 97.519 & $47,55 \%$ \\
\hline Dec 2011 & 145.467 & $49,17 \%$ \\
\hline Dec 2012 & 195.018 & $34,06 \%$ \\
\hline Dec 2013 & 242.276 & $24,23 \%$ \\
\hline Dec 2014 & 272.343 & $12,41 \%$ \\
\hline Dec 2015 & 296.262 & $8,78 \%$ \\
\hline Dec 2016 & 356.504 & $20,33 \%$ \\
\hline Dec 2017 & 424.181 & $18,98 \%$ \\
\hline Dec 2018 & 477.327 & $12,53 \%$ \\
\hline Dec 2019 & 524.564 & $9,90 \%$ \\
\hline
\end{tabular}

Source: Islamic Banking Statistics 2009-2019

Based on table 1, it can be seen that the growth of Islamic bank assets continued to decline between 2012 and 2015. Then the growth of assets increased by $20.33 \%$ in 2016 but again decreased in 2017 until the end of 2019. Even though there was an increase in asset growth in in 2016 with a growth of more than $20 \%$ but until now the rate of growth in Islamic bank assets has not been able to stabilize and has decreased (2). This phenomenon of decreasing growth in Islamic bank assets is the reason for the need to conduct research on what factors affect the growth of Islamic bank assets.

West Java Province has a very important role in the development of the Islamic economy in Indonesia. As a province with the largest population nationally, namely 46.5 million people and 98 percent of the population is Muslim, West Java has a number of human resource factors that have the potential to be developed and directed to be the main driving force for the development of the Islamic economy in Indonesia. In West Java Province, total assets of Islamic banking grew higher than the total assets of national Islamic banking. As of June 2017, Islamic banking assets in West Java grew by 15.8\%. This figure exceeds the national average of only 10 percent. On the other hand, the condition of sharia financial developments in West Java, which was observed in the second quarter of 2017, has increased. This was driven by the increasing growth of Islamic general banking financing in West Java. Until the second quarter of 2017, the growth of sharia financing in West Java was 10.6\%, an increase from the first quarter of 2017 of $8.4 \%$. Meanwhile, Islamic banking third party funds (DPK) in West Java in the second quarter of 2017 also recorded stable growth of $14.2 \%$ compared to the first quarter of 2017 (3).

Based on the research results, one of the variables that has an impact on the growth of Islamic bank assets is the number of Islamic bank office networks. The opening of a network of Islamic bank offices is aimed at providing the public with banking services based on sharia principles. Opening a network of Islamic bank offices can be in the form of a branch office or a sharia business unit scheme. It is expected that the increasing number of bank branch offices will further increase the growth of assets of Islamic banks. (5) in his research proved that the addition of bank office networks has an effect on the growth of Islamic bank assets. However, the results of the study (2) found that the number of offices did not affect the growth of Islamic commercial bank assets. 
The results also show that the variable that affects the growth of Islamic bank assets is problem financing. Non-performing financing is defined as financing that is categorized as substandard, doubtful, and non-performing, in accordance with the provisions of Bank Indonesia as a banking regulator, which is based on an assessment of several things, namely business prospects, customer performance and ability to pay (6). The high level of problem financing indicates the poor quality of Islamic bank financing. The higher the financing problem, the impact on the decline in the growth of Islamic bank assets. Non-performing financing can be seen from the Non-Performing Financing (NPF) ratio. Research (4) shows that Non-Performing Financing (NPF) in the short term has a negative and significant relationship to the growth of Islamic banking assets in Indonesia. Findings (2) also show that Non-Performing Financing has an effect on the growth of Islamic commercial banks' assets. Likewise research (7) and (8) which states that NPF affects the growth of Islamic bank assets in Indonesia. In contrast to research (9) which found that NPF has no effect on the growth of Islamic banking assets in Indonesia.

Another variable according to research results that affects the growth of Islamic bank assets is the Financing to Deposit Ratio (FDR). The FDR demonstrates the banking's ability to channel funds to debtors as well as repay them to depositors by relying on channeled financing as a source of liquidity. According to research (9) the FDR variable affects the growth of Islamic bank assets. Similarly, research (2) proves that the Financing to Deposit Ratio has an effect on the growth of Islamic commercial bank assets. This contrasts with findings (7) and (8) which state that FDR has no effect on the growth of Islamic bank assets in Indonesia.

Some research results also show that the variable affecting the growth of Islamic bank assets is yield. Yield is a concept for returning or giving a share of an investment that has been made based on a certain period or time. The yield ratio is an important factor in determining the yield in Islamic banks (10). Research conducted by (11) shows that the percentage of the yield ratio affects the growth of Islamic bank assets. However, research (2) shows that yields have no effect on the growth of Islamic commercial banks' assets.

The results of previous studies also found that the variable that affects the growth of Islamic bank assets is the BI rate. The BI rate is the benchmark interest rate set by Bank Indonesia with a period of one month. Fluctuations in the BI rate as the reference interest will be followed by fluctuations in interest rates at conventional banks. For conventional banks, interest is important to attract investors to invest their capital in a bank. The higher the interest rate, the more interested investors will be to save. Islamic banks work using an interest-free system, but use a profit-sharing system so that profits and losses are shared between shahibul maal and mudarib. Fluctuations in the BI rate followed by fluctuations in conventional bank interest rates can have an impact on Islamic banks in terms of the competitiveness of Islamic bank products, especially in raising funds from the public. In Islamic banks, if BI raises the interest, the impact on Islamic banks is the cessation of growth in third party funds. Whereas in conventional banks, if BI increases its interest rates, what happens is a decrease in the conventional bank's profit margin. If the BI rate rises, Islamic banking products will become uncompetitive because customers prefer to save their funds in conventional banks whose interest rates also increase following the increase in the BI rate so that it can result in a decline or growth that is not on target in Islamic bank's Third Party Funds. However, when the BI rate decreases, the products of Islamic banks will be more competitive and more customers will want to save their funds in Islamic banks. The reduction in the BI rate makes Islamic banks more attractive to customers than the interest offered by 
non-Islamic banks. Findings (12) indicate that the BI rate has a negative effect on the growth of Islamic bank assets in Indonesia. Meanwhile, research (8) found that there is no effect of the BI rate on the growth of Islamic bank assets in Indonesia.

\section{Research Methods}

\subsection{Asset Growth}

Assets are economic benefits obtained in the future, which are controlled or controlled by the company, and are the result of past transactions or events. Total assets are the total assets owned by a financial company or institution that is used to support the operations of the company or financial institution. Islamic bank assets include cash, placement of funds with Bank Indonesia, placements with other banks, the amount of financing provided, participation, allowance for earning assets losses, fixed assets and inventory, as well as various assets.

The growth of Islamic bank assets referred to in this study is monthly data on the number of BUS and UUS assets in West Java Province obtained from Islamic Banking Statistics released officially by the Financial Services Authority (OJK) during the period 2016 to 2019, which then calculates the growth rate. .

\subsection{Number of Office Networks}

The sharia bank office network consists of operational head offices / branch offices, sub-branch offices / sharia service units and cash offices. The increasing number of Islamic bank offices, especially in remote areas, is becoming important because with the presence of Islamic bank offices in those remote areas, people who previously did not know what Islamic banking were became more familiar and could easily access Islamic banks. So that later there will be more customers saving in Islamic banks so that it will increase the assets of Islamic banks.

\subsection{Non Performing Financing (NPF)}

In Islamic banks, non-performing financing is called Non-Performing Financing (NPF). NPF is very influential on cost control and at the same time also affects the financing policy that will be carried out by the bank itself. NPF can have an unfavorable impact, especially if the NPF is large in number. An increase in the amount of NPF will increase the amount of Allowance for Earning Asset Losses (PPAP) that the bank needs to establish. If this continues, it will reduce bank capital. Therefore, the ability to manage financing is needed by Islamic banks.

Non Performing Financing(NPF) is financing that does not have a good performance and is classified as substandard, doubtful and loss. The duties of Bank Indonesia (BI) include maintaining and maintaining a sound and trustworthy banking system with the aim of safeguarding the economy. For this reason, BI as the central bank and banking supervisor in Indonesia provides provisions for measuring the assessment of a bank's soundness level. One of BI's provisions regarding NPF is that banks must have an NPF of less than $5 \%$.

\subsection{Financing to Deposit Ratio (FDR)}

The FDR states how far the bank's ability to pay back withdrawals made by depositors by relying on financing as a source of liquidity to debtors. In other words, the amount of money used to provide loans is money that comes from deposits from customers. 
The standard used by Bank Indonesia for the FDR ratio is $80 \%$ to $110 \%$. The high FDR ratio affects the income of Islamic banks so that Islamic banks will provide high returns for investors and depositors. The higher this ratio indicates an increase in the income of Islamic banks so that it has an impact on increasing third party funds and total assets of Islamic banking as a whole.

\subsection{DPK yields}

Yield is a profit sharing system in which the owner of the capital collaborates with the capital manager to carry out business activities. If the business activity generates a profit, it is shared by both and when it experiences a loss it is shared as well. The yield system guarantees fairness and no exploitation of parties.

Yield is a concept for returning or giving a share of an investment that has been made based on a certain period or time. The yield ratio is an important factor in determining the yield in Islamic banks (10). Thus, the ratio aspect is an aspect of the agreement mutually agreed upon by the two parties conducting the transaction until a consensus is reached.

\subsection{BI Rate}

The determination of the interest rate (BI rate) by Bank Indonesia (BI) is a monetary policy that aims to control the inflation rate in Indonesia and simultaneously provides a signal to investors to invest in the Indonesian capital market. According to Bank Indonesia, the interest rate is the expense stated in a certain percentage in the context of borrowing money for a certain period of time.

In Indonesia, as the monetary authority, BI has the BI rate as the main monetary instrument used in open market operations. Fluctuations in the BI rate as the reference interest will be followed by fluctuations in interest rates at conventional banks. For conventional banks, interest is important to attract investors to invest their capital in a bank. The higher the interest rate, the more interested investors will be to save. Meanwhile, Islamic banks work using an interest-free system, but use a profit-sharing system so that profits and losses are shared between shahibul maal and mudarib. Fluctuations in the BI Rate followed by fluctuations in conventional bank interest rates can have an impact on Islamic banks in terms of the competitiveness of Islamic bank products, especially in raising funds from the public. In Islamic banks, if BI raises the interest, the impact on Islamic banks is the cessation of growth in third party funds. If the BI rate rises, Islamic banking products will become uncompetitive because customers prefer to save their funds in conventional banks whose interest rates also increase following the increase in the BI rate so that it can result in a decline or growth that is not according to the target in Islamic bank's Third Party Funds. However, when the BI rate drops, the Islamic bank products will be more competitive and more and more customers want to save their funds in Islamic banks. The reduction in the BI Rate makes Islamic banks more attractive to customers than the interest offered by non-Islamic banks.

\subsection{Thinking Framework and Hypotheses}

The Effect of Number of Office Networks on Asset Growth

The number of bank office networks has a significant influence on asset growth, because the wider the network of bank offices will increase the collection of funds from the public and banks can use them to increase bank assets.

An increase in the number of Islamic bank offices will have a significant effect on the growth in total assets of Islamic banks. The breadth of the number of office networks will increase business efficiency and increase competition towards improving service quality and 
encouraging innovation in sharia banking products and services. An increase in business efficiency followed by an increase in service quality will help Islamic banks expand the reach of services to the public, so that Islamic banks can be more affordable for people who want to use Islamic banking services, in this case, one of which is the deposit of public funds. So, in the end, indirectly increasing the number of Islamic bank offices will increase the amount of funds that the bank can raise, which will then be used as assets by Islamic banks to be distributed to the community in deficit units or people who need funds.

The results of the study (9) indicate that the number of Islamic bank office networks has an effect on the growth of Islamic bank assets. Likewise (5) proves that the addition of bank office networks has an effect on the growth of Islamic bank assets. Thus the research hypothesis is formulated:

$\mathrm{H}_{1}$ : The number of office networks has an effect on asset growth

\subsection{The Effect of NPF on Asset Growth}

Non-performing financing is very influential on cost control and at the same time also affects the financing policy that will be carried out by the bank itself. Non-performing financing can have an unfortunate impact, especially if the amount is large. An increase in the amount of non-performing financing will increase the amount of Provision for Earning Asset Losses (PPAP) that banks need to establish. If this continues, it will reduce bank capital which will have an impact on decreasing the growth of Islamic bank assets. The higher this ratio, the worse the quality of bank financing, which causes the amount of problem financing to get bigger and cause losses, conversely, if the lower the NPF, it will affect the profit and growth of Islamic banking assets will increase. (13) stated that Non-Performing Financing affects the growth of Islamic bank assets. (7) states that FDR has an effect on the growth of Islamic banking assets in Indonesia. Research (4) shows that Non-Performing Financing (NPF) in the short term has a negative and significant relationship to the growth of Islamic banking assets in Indonesia. The results of research (8) and (2) indicate that Non-Performing Financing has an effect on the growth of assets of Islamic commercial banks in Indonesia. Thus the research hypothesis is formulated:

$\mathrm{H}_{2}$ : NPF has an effect on asset growth

\subsection{The Effect of FDR on Asset Growth}

The FDR demonstrates the banking's ability to channel funds to debtors as well as repay them to depositors by relying on credit as a source of liquidity. The high FDR ratio affects the income of Islamic banks so that Islamic banks will provide high returns for investors and depositors. The higher this ratio indicates an increase in the income of Islamic banks so that it has an impact on increasing third party funds and total assets of Islamic banking as a whole.

Research (9) proves that FDR affects the growth of Islamic bank assets. Research (2) also found that the Financing to Deposit Ratio has an effect on the growth of Islamic commercial bank assets. Similarly, findings (12) prove that FDR has an effect on the growth of Islamic bank assets in Indonesia. Thus the research hypothesis is formulated:

$\mathrm{H}_{3}$ : FDR has an effect on asset growth

\subsection{The Effect of Return on TPF on Asset Growth}

Yield is a concept for returning or giving a share of an investment that has been made based on a certain period or time. The yield ratio is an aspect of the agreement mutually agreed upon by the two parties conducting the transaction until a consensus is reached. 
Research conducted by (11) shows that the percentage of the yield ratio affects the growth of Islamic bank assets. Based on this description, the research hypothesis is proposed:

$\mathrm{H}_{4}$ : TPF yield affects asset growth

\subsection{The Effect of the BI Rate on Asset Growth}

The interest rate set by Bank Indonesia will be the benchmark interest rate for conventional banks. When the BI rate rises, conventional banks will raise interest rates, while Islamic banks cannot. So that in a high BI rate condition, it will cause Islamic banks to become uncompetitive and reduce the total assets received by Islamic banks which will have an impact on decreasing asset growth as well. The higher the Bank Indonesia interest rate, the lower the growth rate of Islamic bank assets. The results of research (12) prove that the BI rate has an influence on the growth of Islamic bank assets in Indonesia. Based on the logic of thinking and the results of previous research, the following research hypothesis is compiled: $\mathrm{H}_{5}$ : BI rate affects asset growth

Based on the descriptions and results of previous research, the picture of the framework in this study is as follows:

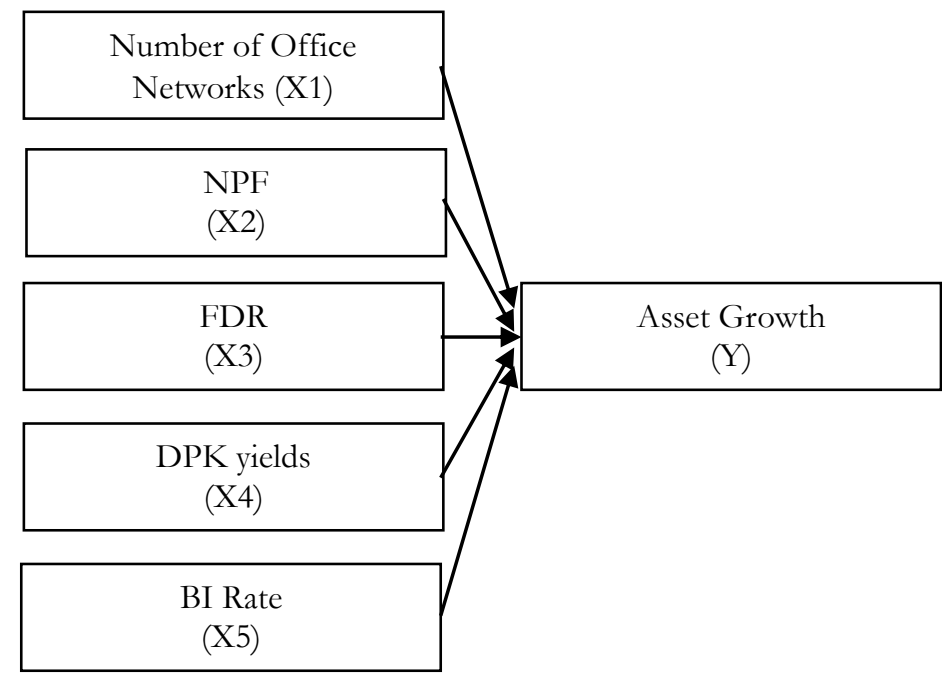

Figure 1. Framework

\section{Research Methods}

\subsection{Research Variable}

The dependent variable in this study is the growth of Islamic bank assets which is the difference between total assets of Islamic banks at time $t$ and the previous month ( $t-1)$ divided by the total assets of the previous month (t-1).

The independent variables are number of office networks, NPF, FDR, DPK yield and $\mathrm{BI}$ rate. The operational dependent and independent variables in this study can be seen in the following table. 
Table 3. Multiple Linear Regression Analysis

\begin{tabular}{|c|l|c|c|}
\hline No. & \multicolumn{1}{|c|}{ Variable } & \multicolumn{1}{|c|}{ Measurement } & Scale \\
\hline 1 & $\begin{array}{l}\text { Asset growth } \\
(Y)\end{array}$ & $\begin{array}{l}\text { Asset Growth = Total Assets t } \text { Total Assets t-1 x 100\% } \\
\text { Total Assets t-1 }\end{array}$ & Ratio \\
\hline 2 & $\begin{array}{l}\text { Number of } \\
\text { office } \\
\text { networks (X1) }\end{array}$ & $\begin{array}{l}\text { Number of branch offices + number of sub-branch } \\
\text { offices }+ \text { number of cash offices }\end{array}$ & Ratio \\
\hline 3 & NPF (X2) & FPF $=\frac{\text { Total Pembiayaan Bermasalah }}{\text { Total Pembiayaan }} \times 100 \%$ & Ratio \\
\hline 4 & FDR (X3) & $\begin{array}{l}\text { Total Pembiayaan } \\
\text { Total DPK } 100 \%\end{array}$ & Ratio \\
\hline 5 & $\begin{array}{l}\text { Return on } \\
\text { DPK (X4) }\end{array}$ & $\begin{array}{l}\text { The ratio of the DPK BUS and UUS returns expressed } \\
\text { as a percentage during the research period }\end{array}$ & Ratio \\
\hline 6 & BI Rate (X5) & $\begin{array}{l}\text { The monthly reference interest rate set by Bank } \\
\text { Indonesia during the study period }\end{array}$ & Ratio \\
\hline
\end{tabular}

\subsection{Population and Sample}

The population in this study were all Sharia Commercial Banks (BUS), Sharia Business Units (UUS) and Sharia Rural Banks (BPRS) which were statistically registered with Bank Indonesia from 2016 to 2019. The research sample is monthly reports. BUS and UUS in West Java Province from January 2016 to December 2019.

\subsection{Data analysis method}

Before the multiple linear regression analysis was carried out, the research data had been carried out and met all the classical assumptions which included the normality test, multicollinearity test, heteroscedasticity test and autocorrelation test.

Multiple linear regression analysis is used to test and analyze the effect of the independent variable on the dependent variable. The following table is used as the basis for compiling the regression equation:

Table 4. Multiple Linear Regression Analysis

\begin{tabular}{|c|c|c|c|c|c|c|}
\hline \multirow{2}{*}{\multicolumn{2}{|c|}{ Model }} & \multicolumn{2}{|c|}{$\begin{array}{c}\text { Unstandardized } \\
\text { Coefficients }\end{array}$} & $\begin{array}{l}\text { Standardized } \\
\text { Coefficients }\end{array}$ & \multirow[t]{2}{*}{$\mathrm{t}$} & \multirow[t]{2}{*}{ Sig. } \\
\hline & & $\mathrm{B}$ & Std. Error & Beta & & \\
\hline \multirow{6}{*}{1} & (Constant) & 39,639 & 27,431 & & 1,445 &, 156 \\
\hline & JMLJARKAN &,- 130 & ,091 &,- 331 & $-1,430$ &, 160 \\
\hline & NPF &,- 311 & ,326 &,- 245 &,- 954 & ,346 \\
\hline & FDR &,- 006 & ,073 &,- 022 &,- 077 & ,939 \\
\hline & IMBHASDPK & 3,029 & 1,430 &, 544 & 2,119 & , 040 \\
\hline & BI_RATE & $-1,030$ & ,581 &,- 403 & $-1,771$ & ,084 \\
\hline
\end{tabular}

a. Dependent Variable: PRTMBHNASET

Source: SPSS Output (2020) follows:

Based on the table above, a multiple linear regression equation can be prepared as

$$
\begin{aligned}
\text { PRTMBHNASET }= & 39,639-0,13 \text { JMLJARKAN }- \text { 0,311 NPF }-0,006 \text { FDR } \\
& +3,029 \text { IMBHASDPK }-1,030 \text { BI_RATE }+ \text { e }
\end{aligned}
$$




\section{Results and Discussion}

Based on table 3 it is found that the first hypothesis is rejected. The results showed that the number of office networks had no effect on the growth of Islamic bank assets. The results of this study are not in line with findings (5) which prove that the addition of bank office networks has an effect on the growth of Islamic bank assets. However, the results of this study are consistent with research conducted by (2) which found that the number of office networks has no effect on the growth of Islamic commercial bank assets. Data on the number of BUS and UUS office networks in West Java Province during the study period, the difference in data is relatively small or not too varied. If we compare it with asset growth data where the data fluctuates sharply or in other words the data is very varied, it can be seen that the number of office networks has no effect on asset growth. In this case, the increase or decrease in the number of BUS and UUS office networks in West Java Province has no impact on the ups and downs of asset growth.

The results showed that NPF had no effect on the growth of Islamic bank assets. This result is in line with research (9) which found that NPF has no effect on the growth of Islamic banking assets in Indonesia. However, the findings in this study are not in line with research (4) which shows that Non-Performing Financing (NPF) in the short term has a negative and significant relationship to the growth of Islamic banking assets in Indonesia. In addition, the results of this study also contradict the findings (2) which proved that non-performing financing has an effect on the growth of Islamic commercial banks' assets. Likewise, the results of research (7) which found that NPF has an effect on the growth of Islamic banking assets in Indonesia is contrary to the findings in this study.

The ratio of NPF BUS and UUS in West Java Province during the study period was still above $5 \%$. In fact, one of BI's provisions regarding NPF is that banks must have an NPF of less than 5\%. Banks should be careful in dealing with NPF-related problems because the higher this ratio, the worse the quality of bank financing, which causes the amount of problem financing to increase which can cause losses. The non-impact of NPF on the growth of Islamic bank assets in West Java Province is possible because the relatively short research period is only four years.

The third hypothesis proposed cannot be accepted. The results of this study fail to prove that FDR has an effect on the growth of Islamic bank assets, in line with studies (7) and (8) which also fail to prove the effect of FDR on the growth of Islamic bank assets in Indonesia. Thus, research (9) which finds that the FDR variable affects the growth of Islamic bank assets and research (2) which proves that the Financing to Deposit Ratio affects the asset growth of Islamic commercial banks is clearly contrary to the findings of this study.

The ratio of FDR BUS and UUS in West Java Province during the study period was within the limit determined by Bank Indonesia, which was in the range of $80 \%$ to $110 \%$. This indicates that BUS and UUS in West Java Province can carry out their roles well as intermediaries between parties with excess funds and those who lack funds. The FDR ratio of $80 \%$ indicates that banks can channel $80 \%$ of the funds collected from the public. If the FDR ratio is more than $110 \%$, it means that the total financing channeled by the bank exceeds the funds raised.

In this study, the size of the FDR ratio does not significantly affect the growth of bank assets. FDR as the ratio of the ability of Islamic banks to channel third party funds in various 
financing schemes, it is very important to know the effect on the growth of Islamic bank assets. FDR does not affect the growth of Islamic bank assets in this study probably due to the short period in this study so that the amount of third party funds channeled back by Islamic banks is not large enough to affect total assets in a short time.

The fourth hypothesis that was proposed failed to be rejected or in other words it was accepted. The results of this study have proven that the TPF yield has an effect on the growth of Islamic bank assets. The results of this study are in line with research conducted by (11) which shows that the percentage of the yield ratio affects the growth of Islamic bank assets. However, this study contradicts research (2) which actually proves that there is no effect of returns on the growth of Islamic commercial banks' assets.

In this case, the percentage of returns on the management of third party funds entrusted by the public to be managed by Islamic banks greatly determines the growth of bank assets. If Islamic banks provide more attractive and competitive returns than conventional banks, the wider community will increasingly entrust the management of their funds to Islamic banks. If more and more third party funds are collected by banks, it will certainly increase the growth of Islamic bank assets more rapidly.

The fifth hypothesis proposed cannot be accepted. The results of this study fail to prove that the BI rate has an effect on the growth of Islamic bank assets. The results of research (12) which prove that the BI rate has an influence on the growth of Islamic bank assets in Indonesia is clearly not in line with the findings of this study. The findings in this study are in line with research (8) which failed to prove the effect of the BI rate on the growth of Islamic bank assets in Indonesia.

In this case, the absence of the influence of the BI rate on the growth of Islamic bank assets is possible because the public tends not to be affected by the BI interest rate or the BI rate when investing their funds in Islamic banks. The conditions might be different if the research was carried out on conventional banking. In addition, it may also be due to the relatively short study period of only 4 years.

\section{Conclusion}

Based on the results of testing the hypothesis, it is concluded as follows:

1. The number of office networks has no effect on the growth of BUS and UUS assets in West Java Province.

2. NPF has no effect on the growth of BUS and UUS assets in West Java Province.

3. FDR has no effect on the growth of BUS and UUS assets in West Java Province.

4. DPK yields affect the growth of BUS and UUS assets in West Java Province.

5. The BI rate has no effect on the growth of BUS and UUS assets in West Java Province.

Of the five independent variables tested and analyzed, the results showed that only the variable yield on deposits had an effect on the growth of assets of BUS and UUS in West Java Province. Referring to this, Islamic commercial banks and sharia business units, especially in West Java Province, should provide competitive and satisfying returns on third party funds to the public, so that they will increasingly attract the wider public to entrust the management of their funds to Islamic banks. This condition will certainly encourage and increase the growth of Islamic bank assets more rapidly. 
After a deeper study, it is known that this study has several limitations, namely the independent variables studied are only five variables so that to increase the confidence of the research results, future research can add other independent variables or add moderating or intervening variables so that it can be more enriching. or add to the variety of research findings. Another limitation is that the research period is relatively short, only four years, so that in the future it can extend the research period so that the research results can be more generalized.

\section{References}

1. Apriyanti HW. Perkembangan Industri Perbankan Syariah di Indonesia: Analisis Peluang dan Tantangan. Maksimum. 2017;01(1):16-23.

2. Supriyanto B, Sari P, Ekonomi F, Surakarta UM. Faktor-Faktor Internal Yang Mempengaruhi Pertumbuhan Aset Bank Umum Syariah Di Indonesia Selama Satu Dekade ( 2009-2018 ). SAMBIS 2019 "Membangun Ekonomi Kreatif yang Berdaya Saing" 2019;368-86.

3. Widayat WS. Pertumbuhan Perbankan Syariah Jabar Lampaui Nasional. 2017; Available from:https://www.republika.co.id/berita/ekonomi/syariahekonomi/17/09/13/ow7mb p383-pertumbuhan-perbankan-syariah-jabar-lampaui-nasional diakses 1 Juni 2020.

4. Dhiba NA, Esya L. Pengaruh NPF, BOPO, GDP Dan SBIS Terhadap Pertumbuhan Aset Perbankan Syariah Di Indonesia. Media Ekonomi. 2019;27(1):9.

5. Ihsan DN. Hubungan Ekspansi Jaringan Kantor dan Kinerja Keuangan Terhadap Pertumbuhan Aset Bank Syariah. Akuntabilitas. 2019;12(1):119-28.

6. Ibrahim A, Rahmati A. Analisis Solutif Penyelesaian Pembiayaan Bermasalah di Bank Syariah: Kajian Pada Produk Murabahah di Bank Muamalat Indonesia Banda Aceh. Iqtishadia - Jurnal Kajian Ekonomi dan Bisnis Islam. 2017;10(1):71-96.

7. Setyawati I. Determinan Pertumbuhan Total Aset Dan Pangsa Pasar Pada Perbankan Syariah. Mediastima Tahun. 2015;XXI(2):80-115.

8. Widyastuti R. Determinan Yang Mempengaruhi Pertumbuhan Total Aset Bank Umum Syariah Di Indonesia 2015-2016. Universitas Islam Indonesia; 2018. Available from: https://dspace.uii.ac.id/bitstream/handle/123456789/10343/tesisfulltext.pdf?sequence $=1 \&$ is Allowed $=\mathrm{y}$.

9. Syafrida I, Abror A. Faktor-Faktor Internal Dan Eksternal Yang Mempengaruhi Pertumbuhan Aset Perbankan Syariah Di Indonesia (Internal and External Factors That Affect the Growth of Sharia Banking Assets in Indonesia). Jurnal Ekonomi Bisnis. 2011;10(1):13446.

10. Arifin M. The Dynamics Study of Regulations on Syariah Banking Indonesia. International Journal Humanity Social Science. 2015;5(3):237-42.

11. Cleopatra Y. Faktor-Faktor yang Mempengaruhi Pertumbuhan Aset Perbankan Syariah di Indonesia. Jurnal Ekonomi dan Bisnis. 2008;Vol. 5, No. 1.

12. Indura AC, Ahmad AA, Suprapto, Arintoko. Analisis Faktor Internal Dan Eksternal Yang Memengaruhi Pertumbuhan Aset Bank Syariah Di Indonesia. Indonesia Journal Islamic Business and Economics. 2019;01.

13. Solihatun. Non Performing Financing. Jurnal Ekonomi Pembangunan. 2014;12(1):5768. Available from: http://journal.unnes.ac.id/sju/index.php/aaj.

14. Ghozali I. Aplikasi Analisis Multivariate Dengan Program IBM SPSS 25 Edisi 9. Semarang: Universitas Diponegoro; 2018. 